\title{
US congressional committee takes on role of reviewer
}

\section{Washington}

A long and painful dispute over the accuracy of a paper published in the journal Cell became a public issue last week.when a US congressional committee took evidence on the case. The dispute seems certain to gain notoriety as it raises fundamental issues of the rights of junior scientists to challenge their co-workers, public access to data on which published papers are based and the ability of scientific institutions to investigate charges of misconduct.

The paper, published in April 1986 (Cell 45, 247; 1986), was written by a team of six, including David Baltimore, a Nobel laureate working at the Massachusetts Institute of Technology (MIT). The other authors were David Weaver, Moema Reis, Christopher Albanese and Thereza Imanishi-Kari of MIT, and Frank Constantini of Columbia University. Imanishi-Kari was the principal author.

Questions about the paper's validity were raised in 1986 by Margot O'Toole, a postdoctoral researcher in ImanishiKari's laboratory. But little was heard in public until a private investigation of the case was attempted by Walter Stewart and Ned Feder, two National Institutes of Health (NIH) scientists known for their tenacious and controversial studies of scientific misconduct. According to their account last week, O'Toole came across 17 pages of records in Imanishi-Kari's laboratory which she recognized as being one part of the experimental data on which the Cell paper was based. After photocopying and analysing the data, she concluded that some of the principal conclusions of the Cell paper were incorrect.

O'Toole pointed out the discrepancies to the authors and urged that a correction be published. But this was not done, nor was O'Toole able to obtain the remainder of the data on which the paper was based. She took her doubts to Dr Henry Wortis of Tufts Medical School and later to Dr Herman Eisen of MIT. Both Wortis and Eisen produced reports on O'Toole's complaint. Neither was made public nor shown to O'Toole but both concluded there was no major error and that a published correction was unnecessary.

Soon after, O'Toole decided not to apply for further grants and abandoned her scientific career. Replying to questions at the congressional hearing, O'Toole said she had wished to continue in research, but as a result of her complaints she felt she had been portrayed as making "ridiculous, trivial and unsubstantiated complaints against my superior for vindictive reasons" and felt unable to do so.

The matter might have rested there if Feder and Stewart had not persuaded her in 1986 to provide them with a copy of the laboratory records. From their own analysis, they concluded that the Cell paper "contained a number of serious misrepresentations of scientific fact". They stressed last week that they do not allege that there is any suspicion of fraud. But when they asked NIH for permission to publish an account of their analysis they found the weight of opinion against them.

Anonymous reviewers selected by NIH stressed that they had no way of assessing the validity of the laboratory notes obtained by O'Toole. As one put it, "the reader is placed in the same position as the receiver of an anonymous telephone call". Another pointed out that an uncontentious explanation of the data is perfectly possible; for instance, that "the authors repeated their experiments elsewhere in their notebooks and found the experiment in question had been the subject of an interpretable experimental error".

$\mathrm{NIH}$ officials urged Feder and Stewart to contact the paper's authors directly. In response, Baltimore, who did not perform the research but has acted as the the team's spokesman, pointed out that the paper had already been the subject of enquiries by "a number of respected immunologists". He rejected the idea that Feder and Stewart should set themselves up "as guardians of scientific purity" and conduct their own investigation of the paper.

Soon afterwards, Baltimore told NIH's deputy director of intramural research, Edward Rall, that if Feder and Stewart were still unsatisfied, the paper should be re-examined by independently chosen immunologists. The offer, described by Rall as "generous", was rejected by Feder and Stewart, who argued that Baltimore's wish that the decision of the committee be binding would restrict "free and open scientific debate".

After further pressure from Feder and Stewart, NIH decided they would after all permit publication of the analysis. But Feder and Stewart could not find a journal willing to accept it. Both Cell and Science turned it down, saying that an impartial committee of inquiry was the way to resolve the issue.

NIH's Mary Miers, head of the misconduct in science office, did indeed begin an investigation. But that too ran into trouble. Two of the first three scientists to be appointed had close links with Baltimore and later left. A new committee is now being formed and will, with luck, reach a conclusion later this year.

Committee members last week did not attempt to judge the scientific merits of the case but were clearly critical of the efficiency of procedures to deal with this

\section{Criminal charge in scientific fraud case}

\section{Washington}

IN what is thought to be the first federal criminal indictment for scientific fraud, Dr Stephen Breuning was charged last Friday with submitting false research results to support a grant application to the National Institute of Mental Health (NIMH). The offence was alleged to have taken place in 1983 when Breuning was at the University of Pittsburgh. Breuning denies the charges. If convicted, he could be fined and sent to prison.

Breuning's case was aired at the same congressional hearing investigating the possibility of error in Imanishi-Kari and colleagues' Cell paper.

Evidence was given by Robert $\mathrm{L}$ Sprague, professor at the University of Illinois, whose allegations first brought the matter to the attention of the NIMH in 1983. He claimed that research reported by Breuning could not possibly have been performed in the limited time allowed for it. Breuning was researching on medicines given to mentally retarded people and the results of his experiments are said to have affected medical practice.

Despite the seriousness of Sprague's allegations, it took three years, and an article in the journal Science, for NIMH to produce a draft report on the case.

In the meantime, Sprague himself was investigated by NIMH. His research grant, which he had received from NIMH continuously for 16 years, was deferred in 1986. NIMH says there is no connection between Sprague's criticisms of NIMH practices and the deferment of his grant, but Sprague said in testimony to the congressional hearing that he seriously doubted that explanation. Alun Anderson

and other cases. There was particular concern that O'Toole felt herself to have been driven out of science and that NIH appears to do little to support those who allege error. Committee members were also critical of the very small resources NIH allocate to oversight. The committee chairman John Dingell expressed shock that NIH "relies completely upon the universities to investigate themselves".

The congressional commitee did not, however, immediately suggest improvements. Some suggestions are that scientific fraud should become subject to criminal proceedings, and that scientists financed by public funds should be required to deposit their laboratory notebooks in public archives. But as Feder and Stewart themselves point out, the last thing that is wanted is "policing of scientific research by authorities outside of science". Alun Anderson 